\title{
ANALIZA PŁATNOŚCI BEZPOŚREDNICH I ICH WPŁYW NA ROZWÓJ OBSZARÓW WIEJSKICH W WOJEWÓDZTWIE PODKARPACKIM
}

\begin{abstract}
Głównym celem artykułu jest dokonanie analizy korzyści wynikających z płatności bezpośrednich i ich wpływ na rozwój obszarów wiejskich w województwie podkarpackim, analizy korzyści z wybranych działań programów PROW 2004-2006 oraz PROW 2007-2013 oraz dokonanie oceny poziomu zadowolenia beneficjentów z tych programów. Podjęto także problem kształtu WPR po 2013 roku, jest to bowiem ważny aspekt z punktu widzenia polskiego sektora rolnego jako elementu polskiej gospodarki. Istotnym elementem wpływającym od roku 2004 na sytuację dochodową polskiego rolnictwa są dopłaty bezpośrednie. Płatności bezpośrednie do gruntów rolnych funkcjonują w ramach I Filaru Wspólnej Polityki Rolnej Unii Europejskiej . Podstawową funkcją tej formy finansowania jest wsparcie dochodów z działalności rolniczej.W opracowanych propozycjach kształtu WPR po 2013 roku najtrudniejszym zadaniem okazało się zrównanie poziomu dopłat we wszystkich krajach członkowskich. W ramach programu PROW 2004-2006 województwo podkarpackie było odbiorcą 3,6\% całej kwoty przeznaczonej dla tego programu, z czego ponad $23 \%$ stanowiły płatności w ramach ONW, a po około $18 \%$ otrzymali renciści strukturalni i gospodarstwa niskotowarowe. Wsparcie w ramach przedsięwzięć rolnośrodowiskowych stanowiło ponad 9\%, a w ramach zalesień ponad 5\% otrzymanej przez województwo kwoty. Najmniejszy procent stanowiły wypłaty w ramach wspierania dostosowywania gospodarstw do standardów unijnych $(3,5 \%)$. Rolnicy z województwa podkarpackiego w latach 2004-2012 otrzymali w sumie 3 mld złotych dopłat bezpośrednich. Dopłaty unijne poprzez Agencję Restrukturyzacji i Modernizacji Rolnictwa otrzymuje co roku średnio 117 tys. rolników z tego województwa. Najwięcej środków finansowych jest kierowanych do rolników w postaci jednolitej płatności obszarowej oraz krajowych płatności uzupełniających (przede wszystkim do grupy upraw podstawowych i do płatności zwierzęcej) oraz oddzielnej płatności cukrowej. Płatności bezpośrednie różnorodnie wpływają na rozwój obszarów wiejskich w województwie podkarpackim. Istnieją możliwości lepszej alokacji płatności bezpośrednich na obszarach wiejskich w tym województwie. W badaniach wykazano, że poziom zadowolenia beneficjentów z możliwości wykorzystania tych środków jest bardzo zróżnicowany. Opinię, że sytuacja nieznacznie się poprawiła, wyraziło $61,01 \%$ respondentów, a zdecydowaną poprawę zauważyło 17,56\% badanych właścicieli gospodarstw z województwa podkarpackiego. Dotacje unijne dla sektora rolnictwa wpływają na poprawę konkurencyjności polskiego sektora rolnictwa.

Słowa kluczowe: płatności bezpośrednie, wspólna polityka rolna
\end{abstract}

\footnotetext{
'mgr Agnieszka Tarapata, Zakład Zarządzania Produkcją, Wydział Zarządzania, Politechnika Warszawska, ul.Narbutta 85, 02-524 Warszawa, tel.kom. 504-585-213, e-mail: agnieszka_tarapata@ poczta.onet.pl
} 


\section{WSTĘP}

Artykuł ten jest efektem rozważań prowadzonych na podstawie opracowań wielu znanych autorów. Istotnym elementem wpływającym od roku 2004 na sytuację dochodowa polskiego rolnictwa są dopłaty bezpośrednie. Płatności bezpośrednie do gruntów rolnych funkcjonują w ramach I Filaru Wspólnej Polityki Rolnej Unii Europejskiej. Podstawowa funkcją tej formy finansowania jest wsparcie dochodów z działalności rolniczej. W niniejszym artykule przedstawiam ewolucję płatności bezpośrednich w ramach reformy wspólnej polityki rolnej. Następnie omawiam politykę rozwoju obszarów wiejskich w województwie podkarpackim. Dokonuję również analizy funduszy unijnych dla województwa podkarpackiego oraz przedstawiam problem kształtu Wspólnej Polityki Rolnej (WPR) po 2013 roku - jest to bowiem ważny aspekt z punktu widzenia polskiego sektora rolnego jako elementu polskiej gospodarki.

\section{EWOLUCJA PLATNOŚCI BEZPOŚREDNICH W RAMACH REFORMY WSPÓLNEJ POLITYKI ROLNEJ}

Dopłaty bezpośrednie wprowadzono w 1992 roku w ramach reformy Wspólnej Polityki Rolnej Mac Sharry'ego, które w wyniku kolejnych reform WPR stały się głównym instrumentem wsparcia rolnictwa. Celem płatności bezpośrednich było rekompensowanie rolnikom spadku ich dochodów spowodowanego znaczną obniżką cen gwarantowanych i stąd ich początkowa nazwa „płatności kompensacyjne”. Dzięki reformie WPR Agenda 2000 dokonano dalszej redukcji cen gwarantowanych/interwencyjnych w zamian za zwiększenie płatności bezpośrednich. Reformy z lat 1992 i 2000 odniosły duży sukces, przyczyniając się do poprawy równowagi rynkowej oraz stabilizacji dochodów rolni$\mathrm{czych}^{2}$. Postanowienia reformy WPR z 2003 roku z Luksemburga wyszły daleko poza dotychczasowe rozwiązania. W wyniku osiagniętego kompromisu wprowadzono system płatności oddzielony od wielkości produkcji (decoupled), który zastąpił większość dotychczasowych płatności bezpośrednich. Reforma ta wprowadziła również zasadę wzajemnej zgodności (cross-compliance), uzależniając wypłacanie rolnikom płatności w pełnej wysokości od utrzymywania gruntów wchodzących w skład gospodarstwa w Dobrej Kulturze Rolnej zgodnie z ochroną środowiska oraz przestrzegania wymogów wzajemnej zgodności z zakresu środowiska, identyfikacji i rejestracji zwierząt (obszar A), zdrowia publicznego, zdrowia zwierząt i roślin (obszar B) oraz dobrostanu zwierząt (obszar C). Zgodnie z reformą WPR uchwaloną w czerwcu 2003 roku, płatności bezpośrednie w Unii Europejskiej są oddzielone od produkcji rolnej, ponieważ ich nadrzędnym celem jest wsparcie dochodów rolniczych, a nie powodowanie zachęt do zwiększania produkcji. Dzięki temu rolnicy dostosowują swoją produkcję do faktycznego zapotrzebowania rynku i swoich przewag konkurencyjnych, a nie kierują się wysokością płatności bezpośrednich. Wypłata wsparcia nie jest zatem powiązana z obowiązkiem prowadzenia określonej produkcji rolnej, a jej wysokość określono na podstawie danych historycznych z okresu referencyjnego. W państwach UE-15 jako okres historyczny przyjęto lata 20002002. W praktyce oznacza to, że rolnicy we Wspólnocie otrzymują określoną kwotę płat-

\footnotetext{
${ }^{2}$ Ministerstwo Rolnictwa i Rozwoju Wsi, www.minrol.gov.pl.
} 
ności w przeliczeniu na gospodarstwo lub hektar użytków rolnych, niezależnie od tego, co uprawiają lub produkują w roku bieżącym. Kontynuacją tej reformy była reforma WPR w roku $2004 \mathrm{w}$ sektorach tytoniu, chmielu, bawełny i oliwy z oliwek, w roku 2005 w sektorze cukru, a w roku 2007 na rynku owoców i warzyw. Głównym celem przyjętych zmian było ujednolicenie form wsparcia w kierunku wsparcia niezwiązanego $\mathrm{z}$ wielkością produkcji. Kontynuacją reformy z Luksemburga jest również porozumienie polityczne z listopada 2008 roku (Health Check). W ramach osiagniętego porozumienia przyjęto działania zmierzające w kierunku oddzielenia wszystkich form wsparcia bezpośredniego od produkcji do 2012 roku. W wyniku kolejnych reform WPR płatności bezpośrednie stały się ważnym instrumentem tej polityki odpowiedzialnym za: wsparcie i stabilizację dochodów rolniczych, utrzymanie użytków rolnych w dobrej kulturze rolnej, zgodnej z wymogami środowiska, rekompensowanie kosztów związanych z wypełnianiem wymogów wspólnotowych (w odniesieniu do jakości i sposobów produkcji) związanych z realizacją pozaprodukcyjnych dóbr publicznych, zapewnienie równych warunków konkurencji $\mathrm{w}$ ramach jednolitego rynku rolno-żywnościowego, a także instrumentem pomocnym w celu realizacji nowych wyzwań, związanych z ochroną zasobów naturalnych, zmianami klimatycznymi, gospodarką wodną, różnorodnością biologiczną oraz energią odnawialną.

\section{SYSTEM PLATNOŚCI BEZPOŚREDNICH STOSOWANY W POLSCE}

Polska, tak jak większość nowych państw członkowskich, zdecydowała o wyborze uproszczonego systemu płatności -system jednolitej płatności obszarowej (SAPS, Single Area Payment Scheme). Poziom płatności bezpośrednich otrzymywanych przez polskich rolników wzrasta corocznie, zgodnie z zasadą stopniowego dochodzenia do pełnego poziomu płatności (tzw. zasada phasing-in) i w roku 2013 wyniosła 100\%. Jednocześnie w Polsce od 2004 roku stosowane są płatności uzupełniające finansowane z budżetu krajowego $^{3}$. Kształtowanie się poziomu płatności w latach 2004-2013 przedstawiono na rys.1.

\footnotetext{
${ }^{3}$ S. Szumski, Wspólna Polityka Rolna Unii Europejskiej, Wydawnictwa Akademickie i Profesjonalne, Warszawa 2007 , s. 37.
} 
Rys. 1. Kształtowanie się poziomu płatności w latach 2004-2013

Fig. 1. Changes in the level of payments in 2004-2013

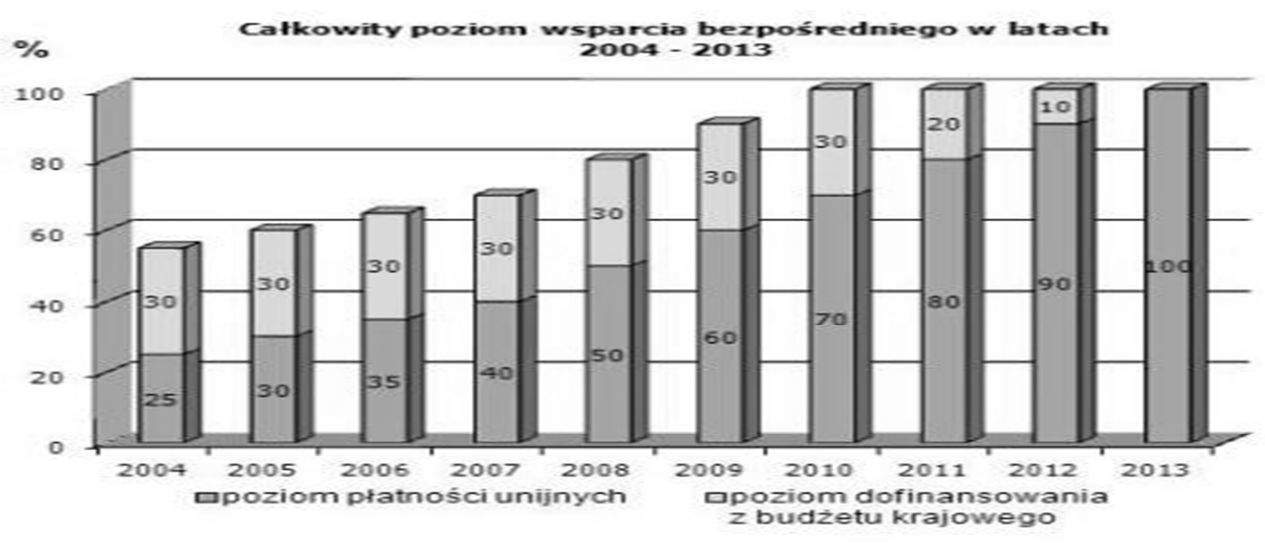

Źródło: Agencja Restrukturyzacji i Modernizacji Rolnictwa, www.arimr.gov.pl

Polscy rolnicy otrzymują te dopłaty od 2004 roku. Dotychczas trafiło do nich w ramach płatności bezpośrednich blisko 86,1 miliarda złotych. W roku 2006 na dopłaty z kasy Unii przeznaczono około 48,5 mld euro, czyli niemal 50\% budżetu Unii. Najwięcej środków finansowych jest kierowanych do rolników w postaci jednolitej płatności obszarowej oraz krajowych płatności uzupełniających (przede wszystkim do grupy upraw podstawowych i do płatności zwierzęcej) oraz oddzielnej płatności cukrowej. Udział poszczególnych płatności w całkowitym wsparciu kierowanym do rolników w 2012 roku przedstawiono na rysunku 2. 
Rys. 2. Udział poszczególnych płatności w całkowitym wsparciu kierowanym do rolników w 2012 roku

Fig. 2. The share of each payment is fully supported by reaching out to farmers in 2012

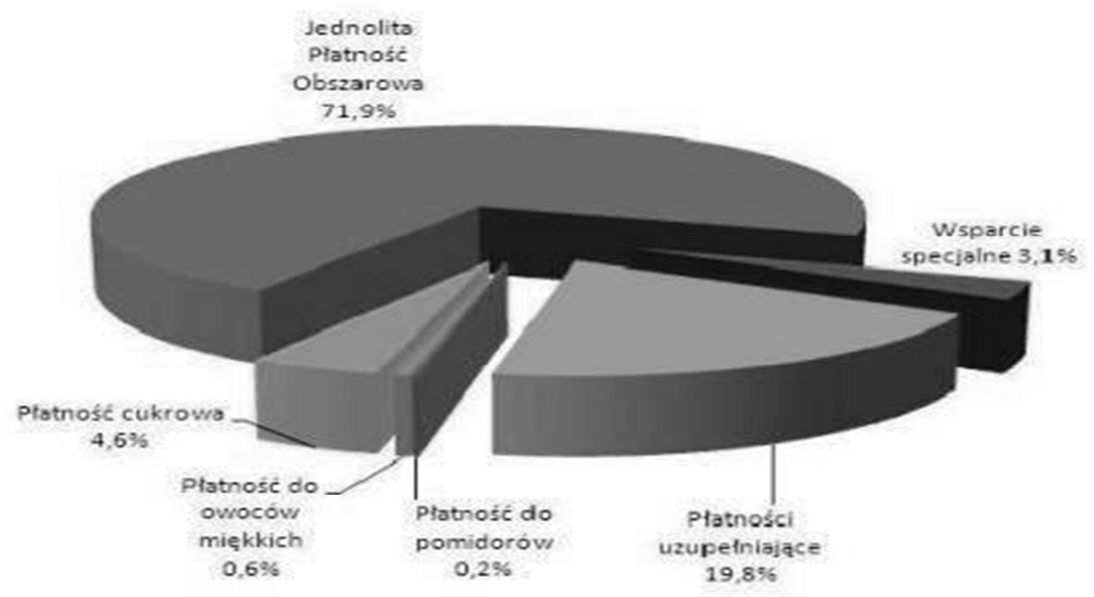

Źródło: Agencja Restrukturyzacji i Modernizacji Rolnictwa, www.arimr.gov.pl

\section{PROGRAM ROZWOJU OBSZARÓW WIEJSKICH 2004-2006 W WOJE- WÓDZTWIE PODKARPACKIM}

W ramach Programu Rozwoju Obszarów Wiejskich (PROW) 2004-2006 województwo podkarpackie było odbiorca $3,6 \%$ całej kwoty przeznaczonej dla tego programu, z czego ponad $23 \%$ stanowiły płatności w ramach obszarów o niekorzystnych warunkach gospodarowania $(\mathrm{ONW})$, a po około $18 \%$ otrzymali renciści strukturalni i gospodarstwa niskotowarowe ${ }^{4}$. Wsparcie $w$ ramach przedsięwzięć rolnośrodowiskowych stanowiło ponad 9\%, a w ramach zalesień ponad 5\% otrzymanej przez województwo kwoty (rys. 3). Najmniejszy procent stanowiły wypłaty $\mathrm{w}$ ramach wspierania dostosowywania gospodarstw do standardów unijnych $(3,5 \%)$.

\footnotetext{
${ }^{4}$ A. Mickiewicz, B. Mickiewicz, Problematyka dopłat bezpośrednich $w$ rolnictwie polskim $w$ latach 2004-2010, „Journal of Agribusiness and Rural Development”, Wydawnictwo Uniwersytetu Przyrodniczego w Poznaniu, Poznań 2011/2.
} 
Rys. 3. Struktura wykorzystania środków PROW 2004-2006 w województwie podkarpackim Fig. 3. Structure of the use of the RDP 2004-2006 in Podkarpackie

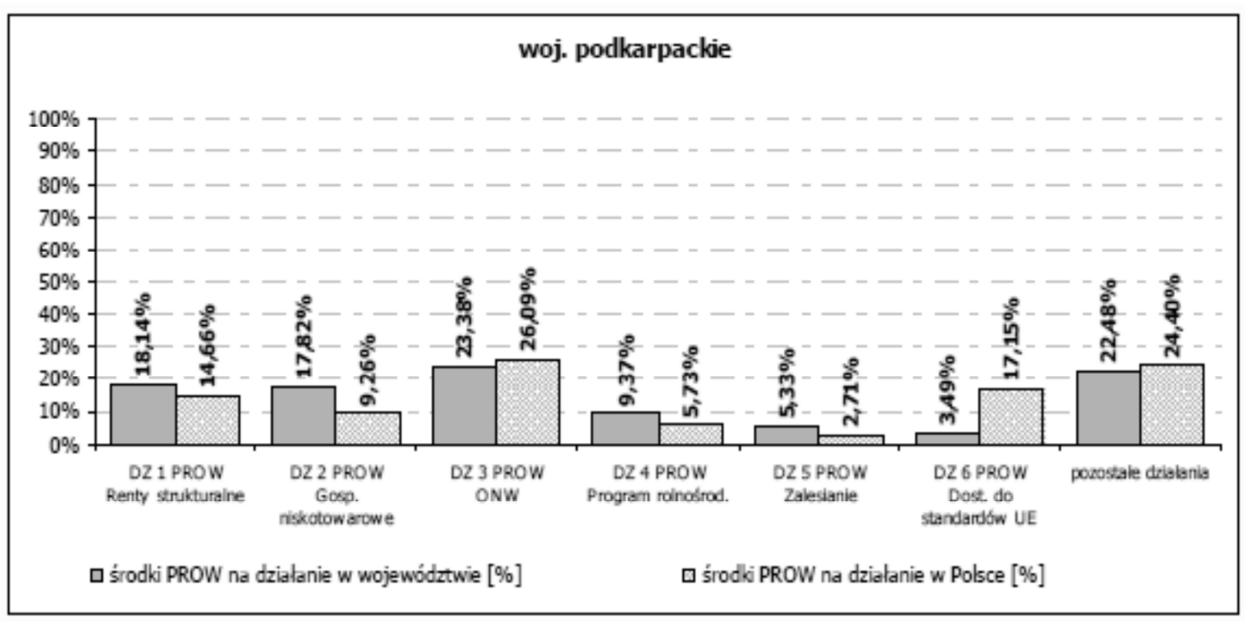

Źródło: Ministerstwo Rolnictwa i Rozwoju Wsi, www.minrol.gov.pl.

Zestawienie płatności w ramach PROW 2004-2006 w województwach przedstawia się następująco na (rys. nr 4.)

Rys. 4. Płatności w ramach Polityka rozwoju obszarów wiejskich 2004-2006 w poszczególnych województwach

Fig. 4. Payments under the Rural Development policy 2004-2006 in different regions

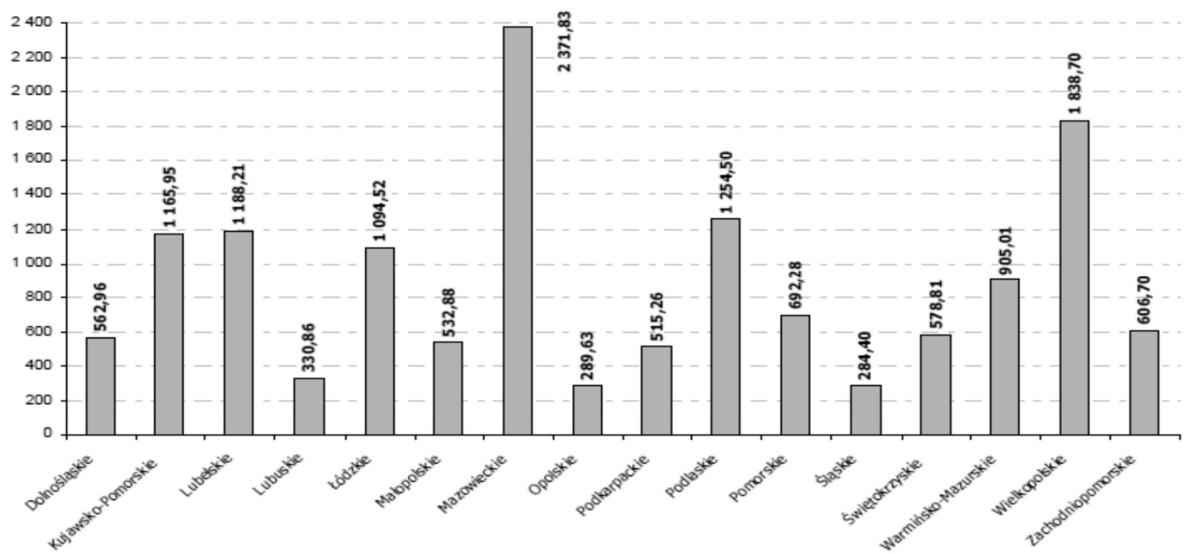

Źródło: Ministerstwo Rolnictwa i Rozwoju Wsi, www.minrol.gov.pl. 


\subsection{OCENA PROGRAMÓW STRUKTURALNYCH W LATACH 2004-2006}

Przeprowadzona ocena wdrażania i realizacji programów strukturalnych w latach 2004-2006 wskazuje, że cechowały je: duża trafność identyfikacji ważnych problemów rozwoju polskiej gospodarki żywnościowej i obszarów wiejskich, uporządkowany, stabilny i przewidywalny obszar oddziaływania, pewność realizacji wyznaczonych celów, przejrzysta struktura finansowania, szeroki wachlarz działań oraz duża dostępność niektórych środków finansowych. Są to niewątpliwie bardzo mocne strony działań strukturalnych wobec wsi i gospodarki żywnościowej.

Do słabych stron polityki strukturalnej wobec wsi i gospodarki żywnościowej w tym okresie należy zaliczyć:

- krótką perspektywę czasową, i rozproszenie środków (w latach 2004-2006 realizowano aż 15 działań programu SPO „Rolnictwo” i 10 działań programu PROW);

- dążenie do maksymalnego wykorzystania środków finansowych UE nawet kosztem efektywności;

- niedostateczne wsparcie rozwoju nowoczesnej gospodarki, przedsiębiorczości i rozwoju zrównoważonego;

- oparcie polskiej polityki strukturalnej na priorytetach europejskich;

- duże opóźnienia w podpisywaniu umów i wypłacie środków, brak skutecznych działań wspierających rozwiązanie problemów bezrobocia na obszarach wiejskich.

\section{FUNDUSZE UNIJNE DLA WOJEWÓDZTWA PODKARPACKIEGO}

W ramach Narodowej Strategii Spójności na lata 2007-2013 do województwa podkarpackiego, na inwestycje realizowane w tym regionie, trafi $1991,23 \mathrm{mln}$ euro funduszy unijnych. Kwota obejmuje alokację na Regionalny Program Operacyjny, regionalny komponent PO Kapitał Ludzki oraz PO Rozwój Polski Wschodniej. Dla porównania w latach 2004-2006 w ramach Zintegrowanego Programu Operacyjnego Rozwoju Regionalnego alokacja dla województwa podkarpackiego wyniosła 192,16 mln euro. Na realizację Regionalnego Programu Operacyjnego województwo podkarpackie otrzymało 1 136,3 mln euro. W ramach regionalnego komponentu PO Kapitał Ludzki Podkarpacie dysponować będzie kwotą 367,46 mln euro. Natomiast w ramach Programu Operacyjnego Rozwój Polski Wschodniej województwo podkarpackie otrzymało 487,47 mln euro. Minister właściwy do spraw rozwoju wsi może określić, za pomocą rozporządzenia, podział środków przeznaczonych na realizację określonych działań w ramach Programu Rozwoju Obszarów Wiejskich na poszczególne województwa. Zgodnie z zaproponowanym przez Ministerstwo Rolnictwa i Rozwoju Wsi podziałem dla wybranych działań do województwa podkarpackiego trafi około 300,43 mln euro pochodzących z Europejskiego Funduszu Rolnego na rzecz Rozwoju Obszarów Wiejskich. W latach 2007-2015 do województwa podkarpackiego trafi 2 746,91 mln euro w ramach działań objętych Strategią Rozwoju Kraju 2007-2015. Wartość dofinansowania unijnego, obejmująca środki w ramach Narodowej Strategii Spójności oraz Programu Rozwoju Obszarów Wiejskich, szacowana jest na 2 291,66 mln euro. Udział środków krajowych szacowany jest na kwotę 455,25 mln euro. 


\subsection{WSPÓLNA POLITYKA ROLNA 2020}

Komisja Europejska rozważa trzy scenariusze realizacji płatności bezpośrednich.

- Poprawiony status quo

Zastosowanie bardziej sprawiedliwego podziału płatności bezpośrednich między poszczególnymi państwami członkowskimi (przy zachowaniu dotychczasowego systemu).

- Lepiej zbalansowane, ukierunkowane i zrównoważone wsparcie

Zastosowanie bardziej sprawiedliwego podziału płatności bezpośrednich. Płatności będą się składać ze stawki podstawowej, obowiązkowej - dodatkowej pomocy za ,zielone" dobra publiczne, dobrowolnej - dodatkowej pomocy mające specyficzne ograniczenia o charakterze naturalnym, wsparcia dla małych gospodarstw oraz limitów dla dużych gospodarstw rolnych.

- Zakończenie wsparcia rynków i dochodów

Zniesienie płatności bezpośrednich w obecnej formie i zapewnienie dopłat ograniczonych za realizację dóbr publicznych w zakresie środowiska naturalnego.

\section{WNIOSKI}

Rolnicy z województwa podkarpackiego w latach 2004-2012 otrzymali w sumie 3 mld złotych dopłat bezpośrednich. Dopłaty unijne poprzez Agencję Restrukturyzacji i Modernizacji Rolnictwa otrzymuje co roku średnio 117 tys. rolników z tego województwa. Najwięcej środków finansowych jest kierowanych do rolników w postaci jednolitej płatności obszarowej oraz krajowych płatności uzupełniających (przede wszystkim do grupy upraw podstawowych i do płatności zwierzęcej) oraz oddzielnej płatności cukrowej. Płatności bezpośrednie różnorodnie wpływają na rozwój obszarów wiejskich w województwie podkarpackim. Istnieją możliwości lepszej alokacji płatności bezpośrednich na obszarach wiejskich w tym województwie. W badaniach wykazano, że poziom zadowolenia beneficjentów z możliwości wykorzystania tych środków jest bardzo zróżnicowany. Opinię, że sytuacja nieznacznie się poprawiła, wyraziło 61,01\% respondentów, a zdecydowaną poprawę zauważyło $17,56 \%$ badanych właścicieli gospodarstw z województwa podkarpackiego.

\section{LITERATURA}

[1] Ministerstwo Rolnictwa i Rozwoju Wsi, www.minrol.gov.pl.

[2] Szumski S., Wspólna Polityka Rolna Unii Europejskiej, Wydawnictwa Akademickie i Profesjonalne, Warszawa 2007.

[3] Mickiewicz B., Mickiewicz A., Problematyka dopłat bezpośrednich $w$ rolnictwie polskim w latach 2004-2010, „Journal of Agribusiness and Rural Development”, Wydawnictwo Uniwersytetu Przyrodniczego w Poznaniu, Poznań 2011/2.

[4] Marks-Bielska R., Babuchowska K., Funkcjonowanie systemu dopłat bezpośrednich w Polsce $i$ innych krajach UE, ,Journal of Agribusiness and Rural Development", Wydawnictwo Uniwersytetu Przyrodniczego w Poznaniu, Poznań 2010/3.

[5] Krzyżanowski J.T., Wspólna Polityka Rolna Unii Europejskiej. Wybrane Zagadnienia, Wydawnictwo SGGW, Warszawa 2009.

[6] Agencja Restrukturyzacji i Modernizacji Rolnictwa, www.arimr.gov.pl. 


\section{ANALYSIS OF DIRECT PAYMENTS AND THEIR IMPACT ON RURAL DE- VELOPMENT IN THE PROVINCE OF PODKARPACKIE}

The main purpose of this article is to analyze the benefits of direct payments and their impact on rural development in the Subcarpathian region, benefit analysis of selected activities and programs of the RDP 2004-2006 RDP 2007-2013, and to assess the level of satisfaction of the beneficiaries of these programs. There has also been discussed a problem of the CAP after 2013, as an important aspect from the point of view of the Polish agricultural sector, as a part of the Polish economy. In the developed proposals of the CAP after 2013 the equalizing the level of payments in all Member States was one of the most significant problems. An important factor contributing since 2004 to the income situation of Polish agriculture are direct subsidies. Direct payments to agricultural land exist within Pillar of the Common Agricultural Policy of the European Union. The primary function of this form of financing is to support farm incomes. Under the RDP 2004-2006 was the recipient of the Subcarpathian region of $3.6 \%$ of the total amount allocated for this program, of which more than $23 \%$ of payments under the LFA, and after about $18 \%$ of pensioners receive structured and semi-subsistence farms. Support under agri-environment accounted for more than $9 \%$, and in the context of afforestation of more than $5 \%$ of the amount received by the province. The smallest payout percent were in support of farmers to adapt to EU standards (3.5\%). Farmers of the region in the years 2004-2012 received a total of 3 billion in direct payments. EU subsidies by the Agency for Restructuring and Modernisation of Agriculture receives an annual average of 117 thousand farmers in the province. Most of the funds are directed to farmers in the form of SAPS and national complementary payments (mainly to the group of basic crops and livestock payments) and the separate sugar payment. Direct payments variously affect the development of rural areas in the Subcarpathian province. There are opportunities for a better allocation of direct payments in rural areas of the province. Studies have shown that the level of satisfaction of the beneficiaries of the possible use of these funds is very diverse. The opinion that the situation improved slightly expressed $61,01 \%$ of the respondents noted a significant improvement of $17.56 \%$ of the surveyed owners of the Subcarpathian Voivodeship. EU subsidies for agriculture are improving the competitiveness of Polish agriculture sector.

Keywords: direct payments, Common Agricultural Policy

DOI: 10.7862/rz.2013.mmr.62

Tekst złożono w redakcji: wrzesień 2013

Przyjęto do druku: grudzień 2013 